\title{
Effects of macrophage colony-stimulating factor on folliculogenesis in gonadotrophin-primed immature rats
}

\author{
K. Nishimura, N. Tanaka, A. Ohshige, Y. Fukumatsu, K. Matsuura and \\ H. Okamura
}

Department of Obstetrics and Gynecology, Kumamoto University School of Medicine, Kumamoto 860, Japan

\begin{abstract}
The effect of macrophage colony-stimulating factor (M-CSF) on folliculogenesis and ovulation was studied. Folliculogenesis and ovulation were induced in immature female rats with a s.c. injection of equine chorionic gonadotrophin (eCG), followed $48 \mathrm{~h}$ later by human chorionic gonadotrophin ( $\mathrm{hCG}$ ). The ovulation rate was measured after the following treatments. (1) Graded doses of human M-CSF $\left(1-300 \times 10^{3}\right.$ iu per rat) were administered i.p. daily for 3 consecutive days. (2) M-CSF $\left(100 \times 10^{3} \mathrm{iu}\right)$ was administered i.p. at designated times between $96 \mathrm{~h}$ before and $10 \mathrm{~h}$ after hCG injection. (3) Rabbit anti-human M-CSF polyclonal antibody $(5 \mu \mathrm{g})$ was administered into the left ovarian bursa at designated times between $49 \mathrm{~h}$ before and $10 \mathrm{~h}$ after hCG injection. In addition, the effect of M-CSF on ovarian macrophages was investigated using immunohistochemistry with mouse anti-rat macrophage monoclonal antibody, TRPM-3. The treatment with M-CSF ( $>30 \times 10^{3}$ iu per rat) significantly increased the ovulation compared with controls in a dose-dependent manner. This stimulatory effect of M-CSF was observed when it was administered between $96 \mathrm{~h}$ and $49 \mathrm{~h}$ before hCG injection. The ovarian intrabursal administration of anti-M-CSF antibody significantly inhibited the number of ovulated ova from the treated ovaries compared with either those from control rats or from the contralateral untreated ovaries between $24 \mathrm{~h}$ before and $3 \mathrm{~h}$ after hCG injection. The immunohistochemistry revealed that M-CSF increased the number of ovarian macrophages in growing follicles. The results suggest that M-CSF is involved in the process of folliculogenesis and that it promotes ovulation by influencing ovarian macrophages.
\end{abstract}

\section{Introduction}

Macrophage colony-stimulating factor (M-CSF), also known as colony-stimulating factor 1 (CSF-1), is a glycoprotein that belongs to the family of haematopoietic growth factors (Clark and Kamen, 1987). These growth factors regulate the production of blood cells, from bone marrow progenitors to mature circulating elements (Clark and Kamen, 1987). Since M-CSF was purified to homogeneity and its genes were cloned and expressed (Stanley and Heard, 1977; Kawasaki et al., 1985; Wong et al., 1987; Ceretti et al., 1988), diverse effects and functions have been reported. M-CSF induces proliferation and differentiation of monocyte-macrophage progenitor cells in bone marrow (Stanley and Heard, 1977; Tushinski et al., 1982; Stanley et al, 1983; Tushinski and Stanley, 1983), and acts on mature monocytes and macrophages to maintain their survival (Tushinski et al, 1982; Becker et al., 1987) and promote their essential biological functions (Tushinski et al., 1982; Warren and Ralph, 1986; Wang et al., 1988). M-CSF has indirect effects on cellular proliferation and differentiation through the stimu-

Received 5 December 1994 lation of cytokine production and release by macrophages (Baird et al., 1985; Assoian et al., 1987; Rom et al., 1988; Fukuoka et al., 1989; Higashiyama et al., 1991). Furthermore, M-CSF acts as a regulator of placenta (Pollard et al., 1987; Arceci et al., 1989; Saji et al., 1990) or trophoblast (Regenstreif and Rossant, 1989; Beauchamp and Croy, 1991) growth and differentiation, and a role in fetal development has also been suggested (Bradley et al., 1971; Bartocci et al., 1986; Azuma et al., 1991).

Macrophages are found within the corpus luteum of several species (Bulmer, 1964; Guillim et al., 1969), and are recognized as mediators that modulate its function and development (Halme et al., 1985). Katabuchi et al. (1989) reported that macrophages are also identified within human growing follicles, and Fukumatsu et al. (1992) reported that they promote the proliferation of granulosa cells as local mediators in rat growing follicles.

In this study, we investigated the effect of M-CSF on folliculogenesis and ovulation and on ovarian macrophages in gonadotrophin-primed immature rats, to determine whether M-CSF and macrophages are involved in the process of folliculogenesis and ovulation. 


\section{Materials and Methods}

Induction of folliculogenesis and ovulation

Immature female Wistar rats were obtained from Kyudo Co. Ltd (Kumamoto) and were housed under controlled laboratory conditions. At $09: 00 \mathrm{~h}$ on day 23 of life, folliculogenesis was induced with a s.c. injection of 5 iu (in the experiments to test the stimulatory effect of M-CSF on a normal ovulation model) or 10 iu (in the experiments to test the inhibitory effect of anti-M-CSF antibody on a superovulation model) equine chorionic gonadotrophin (eCG; Teikoku Hormone Mfg Co. Ltd, Tokyo), and ovulation was induced $48 \mathrm{~h}$ later with a s.c. injection of 10 iu hCG (Mochida Pharmaceutical Co., Tokyo).

The rats were killed by cervical dislocation, and the ovaries and oviducts were removed together $24 \mathrm{~h}$ after hCG injection. The oviducts were separated from the ovaries, placed on a glass slide, and examined under the dissecting microscope. The number of ova released from the ovaries was counted.

\section{Effect of $M-C S F$}

The effects of M-CSF on folliculogenesis and ovulation were examined by administering graded doses $\left(1-300 \times 10^{3}\right.$ iu per rat) of human M-CSF (a formulation of human urine-derived native M-CSF, generic name: Mirimostim; a gift from The Green Cross Co., Osaka) i.p. to the gonadotrophin-primed immature rats daily for 3 consecutive days (i.e. at 48,24 and $\mathrm{o} \mathrm{h}$ before hCG injection). Hence, the total doses of M-CSF administered were $3,9,30,90,300$ or $900 \times 10^{3}$ iu per rat.

The most effective time of M-CSF administration was determined by administering a single injection of $100 \times 10^{3}$ iu M-CSF per rat i.p. to the gonadotrophin-primed rats at 96,72 , 49,24 or $1 \mathrm{~h}$ before, or 3 or $10 \mathrm{~h}$ after hCG injection. M-CSF was dissolved in $250 \mu \mathrm{l}$ of $0.9 \%(\mathrm{w} / \mathrm{v})$ saline. Control rats were given the same amount of vehicle containing equivalent amounts of human albumin (Sigma Chemical Co., St Louis, $\mathrm{MO}$ ) and D-mannitol (Nakarai Tesque Inc., Kyoto), which were the other components of M-CSF used in this study.

\section{Effect of anti-M-CSF antibody}

Rats were lightly anaesthetized with ether and dorsal incisions were made in the abdominal area. Rabbit anti-human M-CSF polyclonal antibody (Genzyme Co., Boston, MA) was diluted with PBS, and $5 \mu \mathrm{g}$ anti-M-CSF antibody was administered into the left ovarian bursa at 49,24 or $1 \mathrm{~h}$ before, or 3 or $10 \mathrm{~h}$ after hCG injection using a 30 -gauge needle. This is an antibody against affinity-purified recombinant human M-CSF and purified IgG, and does not crossreact with human interleukin 2 (IL-2), IL-4, granulocyte colony-stimulating factor (G-CSF) or granulocyte-macrophage colony-stimulating factor (GM-CSF). In control rats, the same volume of vehicle containing the equivalent amount of rabbit immunoglobulin $G$ (Sigma) was administered intrabursally $24 \mathrm{~h}$ before hCG injection. In each rat, the contralateral (i.e. right) ovary was untreated and served as a control.

\section{Immunohistochemistry}

The effect of M-CSF on ovarian macrophages was determined using immunohistochemistry. M-CSF $\left(100 \times 10^{3} \mathrm{iu}\right.$; $n=5)$ or vehicle solution $(n=5)$ was administered i.p. I h before eCG injection in five rats per treatment. Ovaries were obtained $24 \mathrm{~h}$ after eCG injection and fixed in $2 \%(\mathrm{w} / \mathrm{v})$ periodate-lysine-paraformaldehyde for $6 \mathrm{~h}$ at $4^{\circ} \mathrm{C}$. After washing for $4 \mathrm{~h}$ in PBS containing 10,15 or $20 \%(\mathrm{w} / \mathrm{v})$ sucrose, they were embedded in OCT compound (Miles, Elkhart, IN), and frozen in dry ice-acetone. At its greatest diameter, each ovary was cut into 20 semi-serial sections, $8 \mu \mathrm{m}$ thick, by a cryostat (Sakura Fine Technical Co. Ltd, Tokyo) and dried in air. After inhibition of endogenous peroxidase activity, the sections were incubated with mouse anti-rat macrophage monoclonal antibody, TRPM-3 (Anti-marginal metallophils macrophage, rat; BMA Biomedicals Ltd, Augsto), for $60 \mathrm{~min}$ at room temperature. TRPM-3 binds specifically to certain rat macrophage populations, but not to peripheral blood monocytes, granulocytes or lymphocytes (Takeya et al., 1987). After three washes with PBS for $5 \mathrm{~min}$ each, the sections were incubated for $60 \mathrm{~min}$ in avidin-biotin-peroxidase complex (Hsu et al., 1981). Peroxidase activity was visualized by using 3,3'diaminobenzidine (Sigma) as a substrate in Tris- $\mathrm{HCl}$ buffer $\left(0.05 \mathrm{~mol} \mathrm{l}^{-1}\right.$, $\left.\mathrm{pH} 7.6\right)$ containing $0.01 \%(\mathrm{w} / \mathrm{v}) \mathrm{H}_{2} \mathrm{O}_{2}$. Counterstaining was performed with methylgreen. After the immunohistochemical staining with TRPM-3, the distribution and quantitative analysis of macrophages in growing follicles were performed according to the method of Fukumatsu et al. (1992).

\section{Statistical analyses}

All data were presented as means $\pm \mathrm{SEM}$. The significance of differences between means of groups was determined by the Mann-Whitney U-test, and differences with $P<0.05$ were considered to be significant.

\section{Results}

\section{Effect of $M-C S F$}

When M-CSF was administered daily for 3 consecutive days, more than $30 \times 10^{3}$ iu per rat significantly increased the number of ovulated ova compared with that of control rats in a dose-dependent manner $(P<0.05 ;$ Fig. 1$)$.

When a single injection of $100 \times 10^{3}$ iu M-CSF per rat was given at the designated times between $96 \mathrm{~h}$ before and $10 \mathrm{~h}$ after hCG injection, the ovulation rate was significantly increased between 96 and $49 \mathrm{~h}$ before hCG injection compared with that of the controls $(P<0.05$; Fig. 2). However, when $\mathrm{M}-\mathrm{CSF}$ was given between $24 \mathrm{~h}$ before and $10 \mathrm{~h}$ after hCG injection, it had no significant effect on ovulation.

\section{Effect of anti-M-CSF antibody}

In control rats, there were no significant differences in the number of ovulated ova between the vehicle-treated ovary and the contralateral untreated ovary. There were no significant differences in the number of ovulated ova among the untreated ovaries of each group. Ovarian intrabursal administration of the anti-M-CSF antibody $(5 \mu \mathrm{g})$ significantly reduced the number of ovulated ova between $24 \mathrm{~h}$ before and $10 \mathrm{~h}$ after 


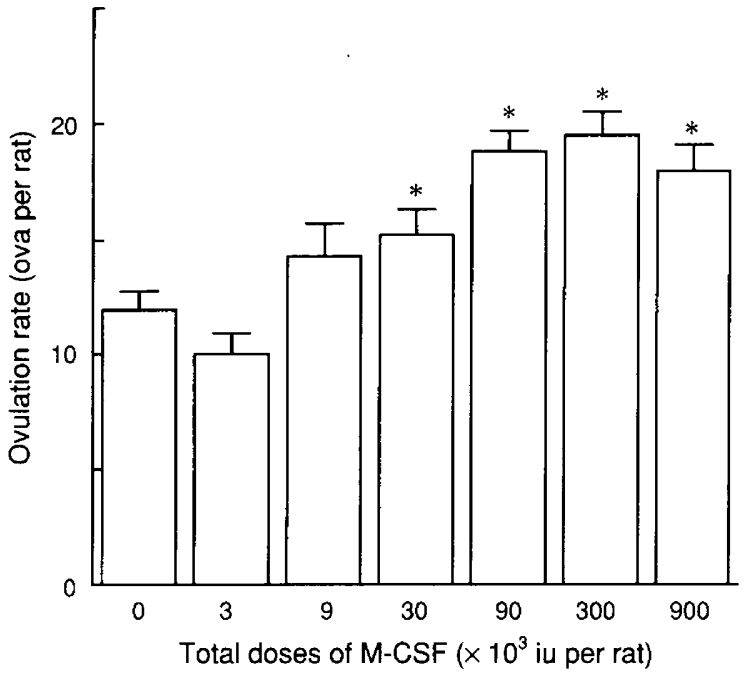

Fig. 1. Effect of macrophage colony-stimulating factor (M-CSF) on ovulation rate in rats. ${ }^{*}$ Significantly different from controls $(P<0.05)$; Number of rats $(n): 16,8,8,9,9,11$ and 9 from left to right columns.

hCG injection compared with the number in contralateral untreated ovaries in each group (inhibition was $41.8-54.1 \%$ ), and between $24 \mathrm{~h}$ before and $3 \mathrm{~h}$ after hCG injection compared with the number in vehicle-treated ovaries of control rats (inhibition was $42.7-47.4 \%)(P<0.05$; Table 1 ). Intrabursal injection of the antibody did not affect the number of ova shed by the contralateral untreated ovaries.

\section{Immunohistochemistry}

Ovarian follicles were classified into three groups according to the greatest diameter of follicles in semi-serial sections: preantral $(<0.15 \mathrm{~mm})$, antral $(0.15-0.3 \mathrm{~mm})$ and mature $(>0.3 \mathrm{~mm})$.

In control rats, preantral follicles were predominant in ovaries obtained $24 \mathrm{~h}$ after eCG injection. M-CSF did not significantly affect the proportion of the three types of follicles when it was administered $1 \mathrm{~h}$ before eCG, although it tended to increase the number of mature follicles.

TRPM-3-positive cells (i.e. macrophages) were found in preantral, antral and mature follicles, but not in all follicles. M-CSF significantly increased the number of follicles with TRPM-3-positive cells, the B:A ratio (the ratio of follicles with TRPM-3 positive cells to follicles per section), and the number of TRPM-3-positive cells per follicle in mature follicles $(P<0.05$; Table 2).

\section{Discussion}

There is increasing evidence that, in addition to pituitary gonadotrophins, ovarian local mediators, including growth factors and cytokines, play an important role in controlling ovarian function (Franchimont et al., 1988; Chen et al., 1993; Brännström et al., 1993a; Tekpetey et al., 1993; Marcinkiewicz et al., 1994). However, little is known about the involvement of $\mathrm{M}-\mathrm{CSF}$ in ovarian function. This is the first report that M-CSF

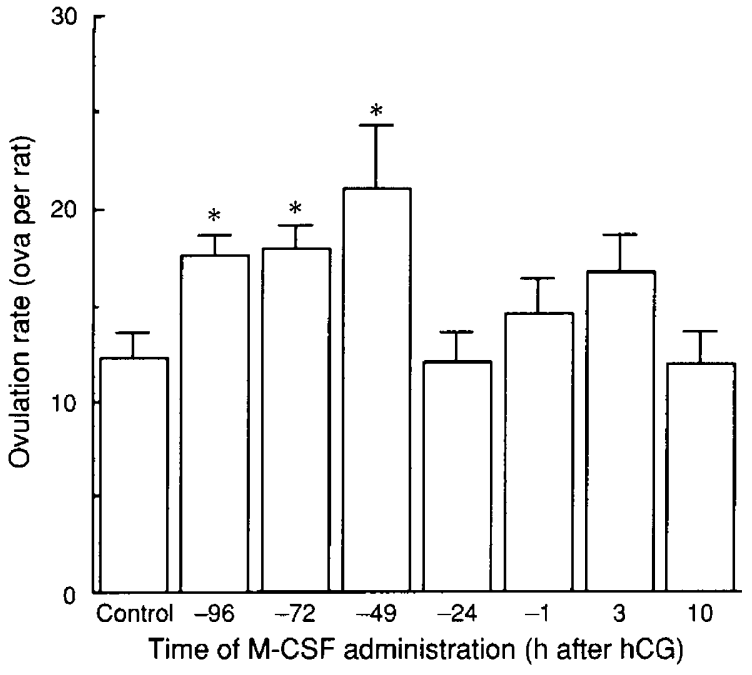

Fig. 2. Optimum time of macrophage colony-stimulating factor (M-CSF) administration on rat ovulation rate. In control rats, only the vehicle was administered i.p. $24 \mathrm{~h}$ before hCG injection. * Significantly different from control values $(P<0.05)$; Number of rats $(n) 9,7,7,8$, $9,9,9$ and 9 from left to right columns.

influences folliculogenesis and ovulation in rats in vivo. Our results showed that M-CSF increased ovulation rate in a dose-dependent manner, and that anti-M-CSF antibody decreased ovulation rate. Ideally, the route of administration of M-CSF and the antibody should be the same. Intrabursal injection for the antibody and the intraperitoneal injection for the M-CSF were chosen because repeated intrabursal injection (accompanied by repeated anaesthesia and laparotomy) damages the bursa, and because after i.p. or i.v. administration, the antibody is rapidly neutralized. In the anti-M-CSF antibody experiment, higher initial ovulation rates were induced so that an inhibitory effect of the antibody would be more obvious.

From the experiments that investigated the effective time of administration of M-CSF and its antibody, a single i.p. injection of M-CSF increased the ovulation rate between $96 \mathrm{~h}$ and $49 \mathrm{~h}$ before hCG injection, and the ovarian intrabursal administration of the antibody decreased ovulation rate between $24 \mathrm{~h}$ before and $3 \mathrm{~h}$ after hCG injection. The results indicated that M-CSF affected folliculogenesis before the hCG injection, rather than the ovulatory process after the hCG injection, and consequently, changed the ovulation rate. The most effective time of M-CSF administation was different from that of the antibody administration. This difference may be due partly to the different design of the experiments. M-CSF may not be effective at a specific time but over a broad period during folliculogenesis, for, at a lower dose, the three-stage administration of M-CSF increased ovulation rate more effectively than did a single injection.

Since ovarian stimulation was controlled completely by exogenous gonadotrophins, the possible effect of M-CSF on the hypothalamic-pituitary axis could be eliminated in our experimental rat model. M-CSF alone could not induce ovulation (data not shown), but appeared to affect folliculogenesis and ovulation in cooperation with gonadotrophins. Since the ovarian intrabursal injection of the anti-M-CSF antibody did not affect the release of ova from the contralateral untreated 
Table 1. Effect of anti-macrophage colony-stimulating factor (M-CSF) antibody on ovulation rate in rats

\begin{tabular}{|c|c|c|c|c|c|}
\hline \multirow{2}{*}{$\begin{array}{l}\text { Time of anti-M-CSF } \\
\text { antibody administration } \\
\text { (h after hCG) }\end{array}$} & \multirow[b]{2}{*}{$n$} & \multicolumn{2}{|c|}{ Number of ova per ovary } & \multicolumn{2}{|c|}{ Percentage inhibition } \\
\hline & & $\begin{array}{c}\text { Untreated } \\
\text { ovary }\end{array}$ & $\begin{array}{l}\text { Treated } \\
\text { ovary }\end{array}$ & $\begin{array}{c}\text { Versus untreated } \\
\text { ovary }\end{array}$ & $\begin{array}{c}\text { Versus control } \\
\text { rat }\end{array}$ \\
\hline Control & 10 & $18.4 \pm 1.9$ & $19.0 \pm 1.4$ & & \\
\hline-49 & 8 & $20.9 \pm 1.1$ & $16.8 \pm 2.1$ & 19.6 & 11.6 \\
\hline-24 & 8 & $19.8 \pm 1.3$ & $10.4 \pm 2.2$ & $47.5^{*}$ & $45.3^{*}$ \\
\hline-1 & 11 & $21.4 \pm 1.4$ & $10.0 \pm 1.7$ & $54.1^{*}$ & $47.4^{*}$ \\
\hline 3 & 7 & $22.6 \pm 2.2$ & $10.9 \pm 1.3$ & $47.1^{*}$ & $42.7^{*}$ \\
\hline 10 & 7 & $19.6 \pm 1.6$ & $11.4 \pm 2.6$ & $41.8^{*}$ & 40.0 \\
\hline
\end{tabular}

Five micrograms of the antibody or vehicle was administered into the left ovarian bursa at the designated times, and the contralateral right ovary was untreated.

*Significantly different from either the contralateral untreated ovaries or the vehicle-treated ovaries of control rats $(P<0.05)$.

Table 2. Quantitative analysis of macrophages in rat growing follicles

\begin{tabular}{|c|c|c|c|c|c|c|}
\hline \multirow[b]{2}{*}{ Parameter } & \multicolumn{2}{|c|}{ Preantral } & \multicolumn{2}{|c|}{ Antral } & \multicolumn{2}{|c|}{ Mature } \\
\hline & Control & M-CSF & Control & M-CSF & Control & M-CSF \\
\hline Number of follicles per section (A) & $14.0 \pm 1.3$ & $13.8 \pm 1.1$ & $7.0 \pm 0.6$ & $8.2 \pm 1.1$ & $3.8 \pm 0.7$ & $4.4 \pm 0.7$ \\
\hline $\begin{array}{l}\text { Number of follicles with TRPM-3-positive cells } \\
\text { per section (B) }\end{array}$ & $0.8 \pm 0.6$ & $1.8 \pm 0.8$ & $2.0 \pm 0.7$ & $3.6 \pm 0.8$ & $0.4 \pm 0.2$ & $1.8 \pm 0.4^{*}$ \\
\hline
\end{tabular}

Macrophage colony-stimulating factor (M-CSF) $\left(100 \times 10^{3}\right.$ iu) or vehicle was administered i.p. to five rats in each group $1 \mathrm{~h}$ before eCG injection. Growing follicles were analysed in 20 semi-serial sections of ovaries obtained $24 \mathrm{~h}$ after eCG injection.

* Significantly different from controls $(P<0.05)$.

ovary, diffusion from the treated ovary to the contralateral untreated ovary was minimal, and M-CSF seemed to act at the ovary.

Since macrophages have been found in atretic follicles and corpora lutea of several species (Bulmer, 1964; Guillim et al., 1969), they were considered to scavenge degenerated cells in the ovary. In addition to their phagocytic function, macrophages produce and release several cytokines such as fibroblast growth factor, transforming growth factor, insulin-like growth factor I, interleukin-1, epidermal growth factor and tumour necrosis factor $\alpha$ (Baird et al., 1985; Assoian et al., 1987; Rom et al., 1988; Fukuoka et al., 1989; Higashiyama et al., 1991; Sancho-Tello et al., 1993), and modulate steroid production by granulosa-luteal cells (Azuma et al., 1991). Brännström et al. (1993b) suggested that macrophages and neutrophilic granulocytes are involved in tissue remodelling that occurs at ovulation. Katabuchi et al. (1989) demonstrated that macrophages are identified not only in the corpus luteum but also in the growing follicles, and Fukumatsu et al. (1992) suggested that macrophages modulate follicular development by influencing the proliferation of granulosa cells. It is therefore possible that M-CSF may act on folliculogenesis and ovulation by influencing ovarian macrophages. In the study reported here, we investigated the effect of M-CSF on the changes in number of ovarian macrophages in growing follicles by using immunohistochemistry. Although TRPM-2 is an anti-rat panmacrophage antibody and recognizes not only macrophages but also monocytes and granulocytes, and TRPM-3 binds specifically to certain rat macrophage populations and does not crossreact with monocytes or granulocytes, there is no difference in distribution or number between the TRPM-2-positive cells and TRPM-3-positive cells in follicles (Fukumatsu et al., 1992). TRPM-3-positive cells can therefore be considered to represent the macrophage population alone. The present results revealed that M-CSF significantly iuncreased the number of macrophages in mature follicles, although the increase in the number of ovarian macrophages was not significant in preantral and antral follicles. This finding suggested that the activation of macrophages may be important in the action of M-CSF on folliculogenesis, although the functional changes of ovarian macrophages were not examined.

Macrophages are known to increase the production of G-CSF and GM-CSF. Brännström et al. (1994) reported that the rat ovary produces GM-CSF before and during the ovulatory process and that there are temporal fluctuations in GM-CSF release with a peak in output at ovulation. In addition to M-CSF, we therefore tested the effect of GM-CSF and G-CSF on folliculogenesis and ovulation. GM-CSF and G-CSF were 
administered i.p. to gonadotrophin-primed immature Wistar rats, and did not stimulate ovulation rate in our experimental model (data not shown).

M-CSF alone may stimulate the ovulation rate, but not through macrophages. Naito et al. (1991) reported that the number of ovarian macrophages is severely reduced in osteopetrotic (op/op) mutant mice, which fail in fertility and production of functional M-CSF (Pollard et al., 1991). Our unpublished observation was that ovulation was inhibited in oplop mice. These findings support the concept that M-CSF plays an important role in the physiology of ovulation directly or through macrophages.

The gene expression of $\mathrm{M}-\mathrm{CSF}$ and its receptor (c-fms proto-oncogene product) has been detected in the uterus and placenta of several species (Pollard et al., 1987; Arceci et al, 1989; Saji et al., 1990). Tekpetey et al. (1992) reported that the mRNA encoding both CSF-1 and its receptor are present in pig granulosa cells, and Arceci et al. (1992) reported that the amount of mRNA encoding c-fms increases during the maturation of mouse oocytes and CSF- 1 is detected in cumulus cells, the oviduct and uterus. These results suggest that M-CSF influences folliculogenesis through direct action on granulosa cells, and that autocrine and paracrine control mechanisms by M-CSF may regulate both follicular and placental development.

In conclusion, our results suggest that M-CSF is involved in folliculogenesis and that it promotes ovulation partly by influencing ovarian macrophages.

This work was supported in part by a grant-in-aid for scientific research from the Ministry of Education (No. 05454454). Part of this paper was presented at 26th Annual Meeting of the Society for the Study of Reproduction in Fort Collins, CO, USA.

\section{References}

Arceci RJ, Shanahan F, Stanley ER and Pollard JW (1989) Temporal expression and location of colony-stimulating factor I (CSF-1) and its receptor in the female reproductive tract are consistent with CSF-1-regulated placental development Proceedings of the National Academy of Sciences USA $\mathbf{8 6}$ 8818-8822

Arceci RJ, Pampfer S and Pollard JW (1992) Expression of CSF-1/c-fms and SF/c-kit mRNA during preimplantation mouse development Developmental Biology 151 1-8

Assoian RK, Fleurdelys BE, Stevenson HC, Miller PJ, Madtes DK, Raines EW, Ross $R$ and Sporn MB (1987) Expression and secretion of type $\beta$ transforming growth factor by activated human macrophages Proceedings of the National Academy of Sciences USA 84 6020-6024

Azuma C, Saji F, Kimura T, Tokugawa Y, Takemura M, Miki M, Ono M and Tanizawa O (1991) The gene expressions of macrophage colony-stimulating factor (MCSF) and MCSF receptor in the human myometrium during pregnancy: regulation by sex steroid hormones Journal of Steroid Biochemistry and Molecular Biology $39883-888$

Baird A, Mormede P and Bohlev P (1985) Immunoreactive fibroblast growth factor in cells of peritoneal exudate suggests its identity with macrophagederived growth factor Biochemical and Biophysical Research Communications 126 358-364

Bartocci A, Pollard JW and Stanley ER (1986) Regulation of colony-stimulating factor 1 during pregnancy Journal of Experimental Medicine 164 956-961

Beauchamp JL and Croy BA (1991) Assessment of expression of the receptor for colony-stimulating factor-1 (fms) in bovine trophoblast Biology of Reproduction 45 811-817

Becker S, Warren MK and Haskill S (1987) Colony stimulating factor induced monocyte survival and differentiation into macrophages in serum free cultures Journal of Immunology 139 3703-3709
Bradley TR, Stanley ER and Sumner MA (1971) Factors from mouse bone marrow cells in vitro Australian Journal of Experimental Biology and Medical Science 49595

Brännström M，Wang L and Norman RJ (1993a) Effects of cytokines on prostaglandin production and steroidogenesis of incubated preovulatory follicles of the rat Biology of Reproduction 48 165-171

Brännström M, Mayrhofer G and Robertson SA (1993b) Localization of leukocyte subsets in the rat ovary during the periovulatory periods Biology of Reproduction 48 277-286

Brännström M, Norman RJ, Seamark RF and Robertson SA (1994) Rat ovary produces cytokines during ovulation Biology of Reproduction 50 88-94

Bulmer D (1964) The histochemistry of ovarian macrophages in the rat Journal of Anatomy $\mathbf{9 8} 313$

Ceretti DP, Wignall J and Anderson D (1988) Human macrophage colony stimulating factor: alternative RNA and protein processing from a single gene Molecular Immunology 25 761-770

Chen H-L, Marcinkiewicz JL, Sancho-Tello M, Hunt JS and Terranova PF (1993) Tumor necrosis factor- $\alpha$ gene expression in mouse oocytes and follicular cells Biology of Reproduction 48 707-714

Clark SC and Kamen R (1987) The human hematopoietic colony stimulating factors Science 236 1229-1237

Franchimont P, Demoulin A and Valcke JC (1988) Endocrine, paracrine and autocrine control of follicular development Hormone and Metabolic Research 20 193-203

Fukumatsu Y, Katabuchi H, Naito M, Takeya M, Takahashi K and Okamura H (1992) Effect of macrophages on proliferation of granulosa cells in the ovary in rats Journal of Reproduction and Fertility 96 241-249

Fukuoka M, Yasuda K, Taii S, Takakura K and Mori T (1989) Interleukin-1 stimulates growth and inhibits progesterone secretion in cultures of porcine granulosa cells Endocrinology 124 884-890

Guillim SW, Christensen KA and MacLennam GE (1969) Fine structure of the human menstrual corpus luteum at its stage of maximum secretory activity American Journal of Anatomy 126409

Halme J, Hammond MG, Syrop CH and Talbert LM (1985) Peritoneal macrophages modulate human granulosa-luteal cell progesterone production Journal of Clinical Endocrinology and Metabolism 61 912-916

Higashiyama S, Abraham JA, Miller J, Fiddes JC and Klagsbrun M (1991) A heparin-binding growth factor secreted by macrophage-like cells that is related to EGF Science 251 936-939

Hsu S-M, Raine L and Fanger H (1981) Use of avidin-biotin peroxidase complex $(A B C)$ in immunoperoxidase techniques. A comparison between $A B C$ and unlabeled antibody (PAP) procedures Journal of Histochemistry and Cytochemistry 29 577-580

Katabuchi H, Fukumatsu Y and Okamura H (1989) Immunohistochemical and morphological observations of macrophages in the human ovary. In Growth Factors and the Ovary pp 409-413 Ed. AN Hirshfield. Plenum Press, New York

Kawasaki ES, Ladner MB, Wang AM, Arsdell JV, Warren MK, Coyne MY, Schweickart VL, Lee M-T, Wilson KJ, Boosman A, Stanley ER, Ralph P and Mark DF (1985) Molecular cloning of a complementary DNA encoding human macrophage-specific colony-stimulating factor (CSF-1) Science $\mathbf{2 3 0}$ 291-296

Marcinkiewicz JL, Krishna A, Cheung CMY and Terranova PF (1994) Oocytic tumor necrosis factor alpha: localization in the neonatal ovary and throughout follicular development in the adult rat Biology of Reproduction 50 $1251-1260$

Naito M, Hayashi S, Yoshida H, Nishikawa S, Shultz LD and Takahashi K (1991) Abnormal differentiation of tissue macrophage populations in 'osteopetrosis' (op) mice defective in the production of macrophage colony-stimulating factor American Journal of Pathology 139 657-667

Pollard JW, Bartocci A, Arceci R, Orlofsky A, Ladner MB and Stanley ER (1987) Apparent role of the macrophage growth factor, CSF-1, in placental development Nature $330484-486$

Pollard JW, Hunt JS, Wiktor-Jedrzejczak W and Stanley ER (1991) A pregnancy defect in the osteopetrotic (oplop) mouse demonstrates the requirement for CSF-1 in female fertility Developmental Biology 148 273-283

Regenstreif LJ and Rossant J (1989) Expression of the c-fms proto-oncogene and of the cytokine, CSF-1, during mouse embryogenesis Developmental Biology 133 284-294

Rom WN, Basset P, Fells GA, Nukiwa T, Trapnell BC and Crystal RG (1988) Alveolar macrophages release an insulin-like growth factor I-type molecule Journal of Clinical Investigation 82 1685-1693 
Saji F, Azuma C, Kimura T, Koyama M, Ohashi K and Tanizawa O (1990) Gene expression of macrophage colony-stimulating factor and its receptor in human placenta and decidua American Journal of Reproductive Immunology 24 99-104

Sancho-Tello M, Tash JS, Roby KF and Terranova PF (1993) Effects of lipopolysaccharide on ovarian function in the pregnant mare serum gonadotropin-treated immature rat Endocrine Journal 1 503-511

Stanley ER and Heard PM (1977) Factors regulating macrophage production and growth. Purification and some properties of the colony stimulating factor from medium conditioned by mouse L cells Journal of Biological Chemistry 252 4305-4312

Stanley ER, Guilbert LJ, Tushinski RJ and Bartelmez SH (1983) CSF-1. A mononuclear phagocyte lineage-specific hemopoietic growth factor Journal of Cellular Biochemistry 21 15I-159

Takeya M, Hsiao L and Takahashi K (1987) A new monoclonal antibody, TRPM-3, binds specifically to certain rat macrophage populations: immunohistochemical and immunoelectron microscopic analysis Journal of Leukocyte Biology 41 187-195

Tekpetey FR, Zhang X, Kovacs P, Rutledge J and Armstrong DT (1992) Colony stimulating factor- 1 ligand (CSF- 1 ) and receptor (CSF-1R) gene expression by porcine granulosa cells and CSF-1 activity in granulosa cell-conditioned medium. In Program of the IX Ovarian Workshop: Serono Symposia p 58 (Abstract)
Tekpetey FR, Engelhardt H and Armstrong DT (1993) Differential modulation of porcine theca, granulosa, and luteal cell steroidgenesis in vitro by tumor necrosis factor Biology of Reproduction 48 936-943

Tushinski RJ and Stanley ER (1983) The regulation of macrophage protein turnover by a colony stimulating factor (CSF-1) Journal of Cellular Physiology $11667-75$

Tushinski RJ, Oliver IT, Guilbert LJ, Tynan PW, Warner JR and Stanley ER (1982) Survival of mononuclear phagocytes depends on a lineagespecific growth factor that the differentiated cells selectively destroy $\mathrm{Cell}_{\mathbf{2 8}}$ $71-81$

Wang JM, Griffin JD, Rambaldi A, Chen ZG and Mantovani A (1988) Induction of monocyte migration by recombinant macrophage colony-stimulating factor Journal of Immunology 141 575-579

Warren MK and Ralph P (1986) Macrophage growth factor CSF-1 stimulates human monocyte production of interferon, tumor necrosis factor, and colony stimulating activity Journal of Immunology 137 2281-2285

Wong GG, Temple PA, Leary AC, Witek-Giannotti JS, Yang Y-C, Ciarletta AB, Chung M, Murtha P, Kriz R, Kaufman RJ, Ferenz CR, Sibley BS, Turner KJ, Hewick RM, Clark SC, Yanai N, Yokota H, Yamada M, Saito M, Motoyoshi K and Takaku F (1987) Human CSF-I: molecular cloning and expression of $4-\mathrm{kb}$ cDNA encoding the human urinary protein Science $\mathbf{2 3 5}$ 1504-1508 